\title{
Metabolic effects of Gum Arabic (Acacia Senegal) in patients with Type 2 Diabetes Mellitus (T2DM): Randomized, placebo controlled double blind trial
}

\author{
Rasha Babiker*1, Khalifa Elmusharaf ${ }^{2}$, Michael B. Keogh ${ }^{3}$, Amin S. I. Banaga ${ }^{4}$, Amal \\ M. Saeed ${ }^{5}$
}

${ }^{1}$ Department of Physiology, Faculty of Medicine, University of Medical Sciences \& Technology UMST, Khartoum, Sudan; ${ }^{2}$ Graduate Entry Medical School, University of LimerickIreland, Limerick, Ireland; ${ }^{3}$ Human Biology and Research Laboratory Manager, School of Medicine, Royal College of Surgeons in Ireland, , Bahrain; ${ }^{4}$ Haemodialysis Unit, Department of Medicine and Nephrology, University of Medical Sciences \& Technology, Academy Charity Teaching Hospital, Khartoum, Sudan; ${ }^{5}$ Department of Physiology, Faculty of Medicine, University of Khartoum, Khartoum, Sudan

*Corresponding author: Dr. Rasha Babiker, Department of Physiology, Faculty of Medicine, University of Medical Sciences \& Technology-UMST, lecturer, P.O Box. 12810, Sudan

Submission Date: January $21^{\text {st }}, 2017$, Acceptance date: March $29^{\text {th }}, 2017$, Publication date: March $31^{\text {st }}, 2017$

Citation: Babiker R., Elmusharaf K., Keogh M.B., Banaga A.S.I., Saeed A.M. Metabolic effects of Gum Arabic (Acacia Senegal) in patients with Type 2 Diabetes Mellitus (T2DM): Randomized, placebo controlled double blind trial. Functional Foods in Health and Disease 2017; 7(3): 219-231

\begin{abstract}
:
Background: Gum Arabic (GA) is a water-soluble dietary fiber, indigestible to both humans and animals. While GA currently does not have any therapeutic potential, it has nutritional value and some effects on metabolism of glucose and lipids. Thus, the aim of this study is to assess the effect of GA on serum level of glucose, lipids, and the BMI in type 2 diabetic patients.
\end{abstract}

Methods: A double-blind randomized placebo-controlled trial took place at Academy Charity Teaching Hospital (ACTH) in Sudan between August 2014 to February 2015. The trial was conducted in type 2 diabetic patients who were on regular oral hypoglycemic drugs and had $\mathrm{HbA} 1 \mathrm{C} \geq 6.5 \%$. Patients excluded from the study included those on insulin, any patient with a metabolic or gastrointestinal disease, and any patient with history of drug addiction and alcoholism. Other patients excluded were patients who had previous allergic reactions to GA in addition to patients who were pregnant or planned for conception within 6 months. 120 patients were invited to participate in this trial. 100 patients gave consent and were randomized to GA and placebo groups. The GA group was given $30 \mathrm{~g}$ of Acacia Senegal and the placebo group was given 
$5 \mathrm{~g}$ of placebo daily for 3 months. The outcomes assessed were primarily the effect of GA on glucose levels in addition to the effects on levels of lipids and BMI in type 2 diabetic patients.

Results: The GA group showed significant reduction in fasting plasma glucose (FPG) and HbA1c $(\mathrm{P}<0.05)$ within the GA group. Moreover, GA supplementation improved lipid profiles; decreased LDL-Cholesterol by $5.95 \%$, total Cholesterol by $8.28 \%$ and triglyceride by $10.95 \%$ from baseline levels. HDL-Cholesterol showed significant increase by $19.89 \%$ within GA group $(\mathrm{P}<0.05)$, BMI was decreased significantly by $2.06 \%(95 \% \mathrm{CI}:-0.98 ;-0.16), \mathrm{P}<0.05)$.

Conclusions: Gum Arabic is a dietary supplement for improving nutrition of type 2 diabetic patients; it has demonstrated a good effect on improving their poor glycemic control. It has also shown improvement in the levels of the lipids and the BMI. Further studies are needed in obese and pre-diabetic patients to evaluate GA therapeutic potentials.

Trial registration: PACTR201403000785219.

Keywords: Gum Arabic, Diabetes Mellitus type 2, Lipid profiles, Fasting Plasma Glucose, Dietary Fibers, HbA1c

\section{BACKGROUND:}

Diabetes is one of the world's fastest growing chronic diseases. As the prevalence of diabetes continues to rise, it will eventually reach a global rise by 2025.According to the International Diabetes Foundation (IDF), there are 415 million people with diabetes in the world. By 2040, the number of diabetes will increase to 642 million worldwide. The greatest increase in the incidence and prevalence of diabetes is in the African population, which is attributed to the dietary habits associated with urbanization and westernization $[1,2]$. Diabetes increases the risk of developing heart diseases [3]. Therefore, the option to reduce this risk by improving dietary habits intake is important, especially through advising diabetic patients to increase their intake of dietary fibers. However, the amount of fiber intake remains low, despite its well-documented effects in the prevention of type 2 diabetes and its complication [4]. Among these dietary fibers is Gum Arabic (GA), which is a water-soluble dietary fiber composed of a mixture of polysaccharides, oligosaccharides, and glycoproteins. It is exudates of Acacia senegal trees with remarkable properties [5]. Gum Arabic dissolves in water, forming a gel-like fluid with a viscous texture. It has the ability to slow the absorption and digestion of carbohydrates by the viscosity effect of dietary fibers [6], which may alter colonic microbial fermentation to generate short chain fatty acid (SCFA) mainly butyrate [7] and thereby possibly reduce the risk of metabolic syndrome [8]. GA improves bowel movements [9] with glycemic control [10,11], and also improves body weight [12]. Therefore, this study was conducted to investigate the beneficial effects of consuming $30 \mathrm{~g}$ of GA with a normal diet for 3 months among type 2 diabetic patients. 


\section{SUBJECTS AND METHODS:}

\section{Methods}

This is a double-blind randomized placebo-controlled trial that took place at the Academy Charity Teaching Hospital (ACTH) in Sudan, carried outfrom August 2014 to February 2015. This study was conducted according to the guidelines by the Declaration of Helsinki and procedures were approved by the Research Ethics Committee - Khartoum State Ministry of Health and the Institutional Review Board at University of Medical Science and Technology (UMST); SUM 116 -IRB number: 00008867 . The trial is registered under PACTR201403000785219.

\section{Patients}

One hundred patients diagnosed with T2DM were recruited in this study from a diabetes outpatient clinic that had their regular medical follow-up at the clinic.

Patients with the following criteria were included in this study: adult diagnosed with type 2 diabetes mellitus, their fasting plasma glucose is (FPG) $\geq 7.0 \mathrm{mmol} / \mathrm{L}(126 \mathrm{mg} / \mathrm{dl}), \mathrm{HbA} 1 \mathrm{c} \geq 6.5 \%$ and on oral hypoglycemic medication.

The exclusion criteria were as follows: alcoholic patients or drug addicts, patients with a history of metabolic or gastrointestinal diseases (chronic degenerative and/or inflammatory diseases), Type 1 diabetes mellitus or diabetic patients on insulin treatment, history of GA allergy, and pregnancy, in addition to women planning to conceive within the next 6 months.

\section{Study design and enrollment}

Only patients approved to participate in this trial by written informed consent were enrolled. Patients were randomized and allocated by generating a series of numbers by independent thirdparty not associated with the study. Accordingly, the chief attending doctor and participants were blinded.

\section{Intervention}

Sealed boxes were prepared containing a supplement from either the intervention GA or pectin (placebo) group. A test group of 46 patients received oral GA of $30 \mathrm{~g} /$ day for three months and a placebo group of 45 patients who received pectin as a placebo for the same period of time. The dose of powder GA was divided in two sachets; each sachet containing 15 grams. The sachets content was poured in a glass cup containing $250 \mathrm{ml}$ of water, and then were added quickly with mixing and shaking to ensure adequate mixing before intake. Both sachets were consumed early morning. The dose of placebo was $5 \mathrm{~g}$ of pectin. Eligible patients were enrolled randomly and allocated either intervention or placebo. No dietary habit restrictions were instructed during the trial. However, the enrolled patients were instructed not to change their lifestyle or physical activities during the study, and to continue taking their oral hypoglycemic drugs as prescribed by their physician. Gum Arabic was provided in a powder form as a gift by "Dar Savanna Ltd. Khartoum, Sudan." Its quality was consistent with the requirements of the Food and Agriculture Organization of the United Nations and British pharmacopoeia [13].

Daily consumption records were reported using a self-reporting checklist sheet. After randomization, a secondary investigator was responsible for enrollment and blinded randomization 
of supplements. Only the study statistician and the data monitor had un-blinded data, but none of them had any contact with study patients.

\section{Outcome measurements}

The primary outcome of this study was the mean percent change of fasting plasma glucose and HbA1c from baseline to the end of 3-months follow-up in the GA group. Secondary outcomes were mean percent changes in BMI, waist circumference, total cholesterol, triglycerides, lowdensity lipoprotein cholesterol (LDL), and high-density lipoprotein cholesterol (HDL). During the pre-intervention period, the patients underwent physical examinations, including waist and hip circumference, body weight, and height. Investigations included in laboratory tests. Blood samples were obtained by veinpuncture, drained in to cryogenic collection tubes, and centrifuged immediately at $2700 \mathrm{rpm}$ for 10 minutes to separate plasma from blood. Biochemical analyses were performed using BioSystems S.A. Spain. A Quality System certified according to EN ISO 13485 and EN ISO 9001 standards to determine lipid profile (total cholesterol, HDL-cholesterol, LDL-cholesterol, and triglyceride levels), and plasma from the glycolytic inhibitor tube was used for measuring fasting plasma glucose level with an international standard for clinical testing laboratories $[14,15]$.

Height and weight were measured before breakfast using a calibrated physician's scale to the nearest $0.1 \mathrm{~cm}$ and $0.1 \mathrm{~kg}$ respectively. BMI was calculated directly as weight divided by height squared. Each waist was measured at the umbilical level in the standing position after the end of light expiration using a measuring tape. These examinations and laboratory tests were performed after an overnight fasting condition (10-12 hours).

\section{Statistics}

Data were collected, with double data entry and cross validation used to ensure the validity and quality of data. Intention to treat analysis was performed in which all patients who were enrolled and randomly allocated are included in the analysis and were analyzed in the groups to which they were randomized. The paired t-test was used for the analysis of pre-and post-intervention data. A $p$-value of less than 0.05 was considered statistically significant.

\section{RESULTS:}

\section{Patient enrollment and intervention}

A total of 120 patients were identified as eligible. However, only 100 patients satisfied the inclusion criteria and were approved to be enrolled. Three patients had declined to participate. During the intervention, two patients got pregnant and were excluded, three patients were found to have violated the instructions, and one patient went into surgical operation due to accidental trauma. Consequently, the analysis was conducted for the remaining 91 patients as shown in (Figure 1).

\section{Characteristics of patients}

The baseline characteristics (mean $\pm \mathrm{SD}$ ) of the 91 patientswere the following: age; $50 \pm 9$ years, duration of diabetes; 61.8 \pm 51.8 months, height; 1.6 (0.09) m, weight; $75 \pm 14.8 \mathrm{~kg}$ and BMI; $28.8 \pm 6.05$. During the first two weeks of the intervention and follow-up periods, minor adverse reactions were detected in patients enrolled (Table 4). 


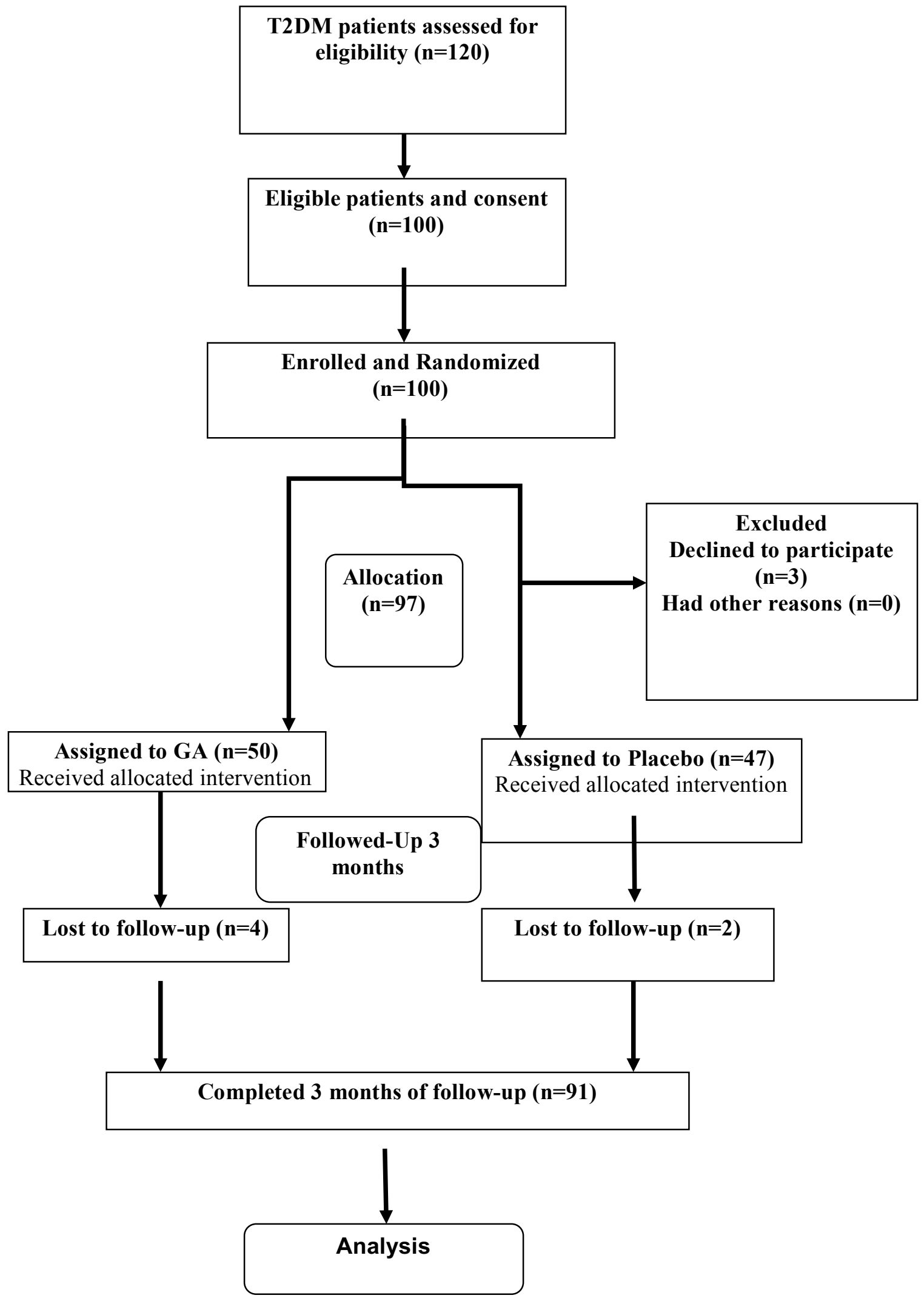

Figure 1: Flow diagram of T2DM patients 


\section{Characteristics and specifications of Gum Arabic}

Table 1: Powdered exudates of Acacia Senegal (Gum Arabic E-414) General specifications

\begin{tabular}{|c|c|}
\hline \multicolumn{2}{|l|}{ Physical Specification } \\
\hline Form & Powder \\
\hline Color & Off White \\
\hline Smell \& Odor & None \\
\hline Taste & Characteristic taste \\
\hline Viscosity of $20 \%$ Solution & $70-110 \mathrm{cp}$ \\
\hline PH of $20 \%$ Solution & $4.1-4.8$ \\
\hline Speck Test & Per standard \\
\hline Moisture & $<13 \%$ \\
\hline Total Ash & $<4 \%$ \\
\hline Acid Insoluble Residue & $<1.0 \%$ \\
\hline Identification & Positive \\
\hline Starch or Dextrin & Negative \\
\hline Tannin Bearing Gums & Negative \\
\hline \multicolumn{2}{|l|}{ Heavy Metals } \\
\hline Arsenic & $<1.0 \mathrm{mg} / \mathrm{kg}$ \\
\hline Lead & $<2.0 \mathrm{mg} / \mathrm{kg}$ \\
\hline Cadmium & $<1.0 \mathrm{mg} / \mathrm{kg}$ \\
\hline Mercury & $0.05 \mathrm{mg} / \mathrm{kg}$ \\
\hline Antimony & $<1.0 \mathrm{mg} / \mathrm{kg}$ \\
\hline Tin & $<40 \mathrm{mg} / \mathrm{kg}$ \\
\hline Copper & $<20 \mathrm{mg} / \mathrm{kg}$ \\
\hline Total Dietary Fibre (As is) & $>85 \%$ \\
\hline Total Dietary Fibre (Dry Weight) & $>90 \%$ \\
\hline \multicolumn{2}{|l|}{ Microbiological specifications } \\
\hline Total Plate Count cfu/g & $\leq 5 \times 105$ \\
\hline Salmonella Abs/Prs in $25 \mathrm{~g}$ & Absent \\
\hline Total E. Coli Count Abs/Prs & Absent \\
\hline Total Yeast \& Mold Count cfu/g & $\leq 5 \times 104$ \\
\hline Enterobacteriaceae PN/g & $\leq 5 \times 103$ \\
\hline Nutritional Information & $\begin{array}{l}\text { (approximate values per } 100 \\
\text { g) }\end{array}$ \\
\hline Energy & $200 \mathrm{Kcal}$ \\
\hline Protein & $1.9 \mathrm{~g}$ \\
\hline Available Carbohydrates & $<0.1 \mathrm{~g}$ \\
\hline Fat & $0.1 \mathrm{~g}$ \\
\hline Soluble Dietary Fibre & $85.5 \mathrm{~g}$ \\
\hline Soluble Dietary Fibre (Dry Basis) & $94 \mathrm{~g}$ \\
\hline Cholesterol & $<1 \mathrm{mg}$ \\
\hline Sodium & $14 \mathrm{mg}$ \\
\hline \multicolumn{2}{|l|}{ Minerals: } \\
\hline Calcium & $1074 \mathrm{mg}$ \\
\hline Potassium & $914 \mathrm{mg}$ \\
\hline Magnesium & $390 \mathrm{mg}$ \\
\hline Iron & $1.0 \mathrm{mg}$ \\
\hline
\end{tabular}


Table 2: Baseline characteristics of participants in Gum Arabic and Placebo intervention groups $(n=91)$.

\begin{tabular}{|c|c|c|c|c|c|c|c|}
\hline \multirow[b]{3}{*}{ Variables } & \multicolumn{2}{|l|}{$\begin{array}{l}\text { Placebo } \\
(n=45)\end{array}$} & \multicolumn{2}{|c|}{$\begin{array}{l}\text { Gum Arabic } \\
(n=46)\end{array}$} & & & \\
\hline & & \multirow[t]{2}{*}{ SEM } & & \multirow[t]{2}{*}{ SEM } & \multirow[t]{2}{*}{$\begin{array}{l}\mathrm{P} \\
\text { value }\end{array}$} & \multicolumn{2}{|c|}{$\begin{array}{l}\text { 95\% C.I of } \\
\text { differences }\end{array}$} \\
\hline & & & & & & $\mathbf{L}$ & $\mathbf{U}$ \\
\hline Age (Years) $^{\text {a }}$ & $50.22 \pm 9.29$ & 1.39 & $49.96 \pm 8.73$ & 1.29 & 0.89 & -4.02 & 3.49 \\
\hline Male $^{b}$ & $6(13.3 \%)$ & & $12(26.1 \%)$ & & \multirow[t]{2}{*}{0.19} & & \\
\hline Female $^{b}$ & $39(86.7 \%)$ & & $34(73.9 \%)$ & & & & \\
\hline Duration of DM (months) $^{a}$ & $59.53 \pm 48.09$ & 7.17 & $64.04 \pm 55.43$ & 8.17 & 0.68 & -17.13 & 26.15 \\
\hline$\leq 60$ months ${ }^{b}$ & $28(62.2 \%)$ & & $26(56.5 \%)$ & & \multirow{3}{*}{-0.83} & & \\
\hline$>60 \& \leq 120^{b}$ & $13(28.9 \%)$ & & $16(34.8 \%)$ & & & & \\
\hline$>120$ months $^{b}$ & $4(8.9)$ & & $4(8.7 \%)$ & & & & \\
\hline Height (cm) $^{a}$ & $161.07 \pm 8.82$ & 1.31 & $162.26 \pm 9.01$ & 1.33 & 0.52 & -2.52 & 4.91 \\
\hline Weight (kg) $^{a}$ & $77.07 \pm 13.84$ & 2.06 & $72.86 \pm 15.72$ & 2.32 & 0.18 & -10.38 & 1.96 \\
\hline $\operatorname{BMI}\left(\mathrm{Kg} / \mathrm{m}^{2}\right)^{a}$ & $29.96 \pm 6.54$ & 0.97 & $27.66 \pm 5.37$ & 0.79 & 0.07 & -4.79 & 0.19 \\
\hline Healthy weight $^{\mathrm{b}}$ & $10(22.2 \%)$ & & $17(37 \%)$ & & \multirow{5}{*}{0.55} & & \\
\hline Overweight $^{b}$ & $18(40 \%)$ & & $17(37 \%)$ & & & & \\
\hline Obesity class $\mathrm{I}^{\mathrm{b}}$ & $11(24.4 \%)$ & & $9(19.6 \%)$ & & & & \\
\hline Obesity class II $^{\mathrm{b}}$ & $2(4.4 \%)$ & & $1(2.2 \%)$ & & & & \\
\hline Obesity class III $^{b}$ & $4(8.9 \%)$ & & $2(4.3 \%)$ & & & & \\
\hline Waist circumferences (cm) & $94.76 \pm 14.9$ & 2.22 & $98.65 \pm 12.41$ & 1.83 & 0.18 & -1.81 & 9.60 \\
\hline More than $102 \mathrm{~cm}$ (male) ${ }^{b}$ & $2(4.4 \%)$ & & $5(10.9 \%)$ & & \multirow{4}{*}{3} & & \\
\hline Less than $102 \mathrm{~cm}$ (male) ${ }^{b}$ & $4(8.9 \%)$ & & $7(15.2 \%)$ & & & & \\
\hline More than $88 \mathrm{~cm}$ (female) ${ }^{b}$ & $27(60 \%)$ & & $27(58.7 \%)$ & & & & \\
\hline Less than 88 (female) ${ }^{b}$ & $12(26.7 \%)$ & & $7(15.2 \%)$ & & & & \\
\hline $\mathbf{H b A 1} 1_{C}(\%)^{a}$ & $9.59 \pm 2.61$ & 0.39 & $9.23 \pm 2.10$ & 0.31 & 0.71 & -1.17 & 0.80 \\
\hline \multicolumn{8}{|l|}{\begin{tabular}{|l|} 
Glucose-lowering medication \\
\end{tabular}} \\
\hline Metformin only ${ }^{b}$ & $19(42.2 \%)$ & & $18(39.1 \%)$ & & \multirow[t]{2}{*}{0.83} & & \\
\hline Combination therapy $^{b}$ & $26(57.8 \%)$ & & $28(60.9 \%)$ & & & & \\
\hline
\end{tabular}

${ }^{\mathbf{a}}$ Mean $\pm \mathrm{SD},{ }^{\mathbf{b}}$ number (percentage) 
Table 3: Effect of Gum Arabic and Placebo on glycemic indicators, serum lipid profiles and BMI pre and post three months intervention $(n=91)$

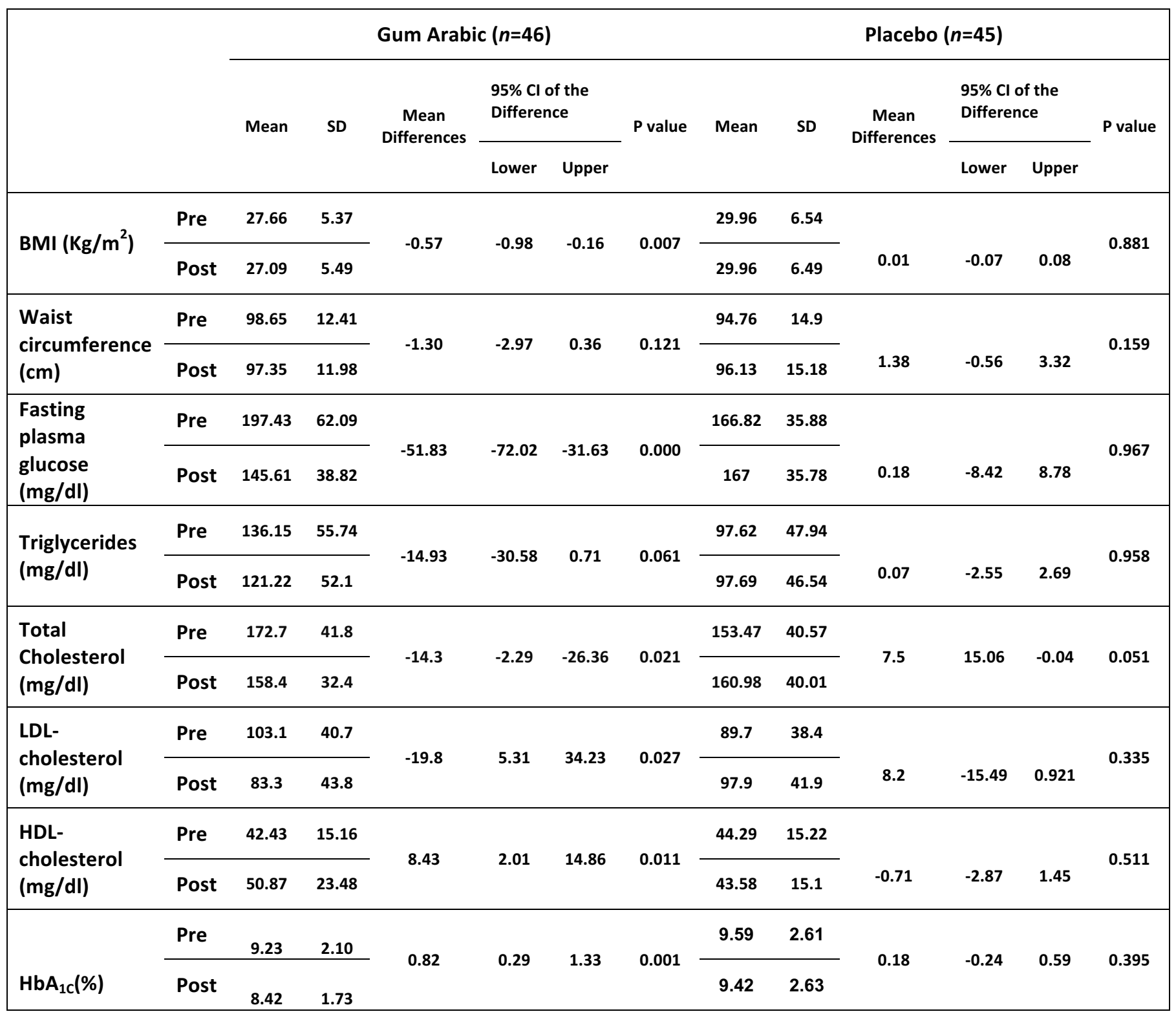

\section{Effects of GA on metabolic elements}

There was a statistically significant reduction of BMI by $2.1 \%$ in the GA group patient after the intervention $(27.09 \pm 5.49$ vs. $27.66 \pm 5.37$ pre-intervention, $\mathrm{p}<0.05)$, while no significant change was observed in the placebo group (Table 3). Statistically, there was no significant change of waist circumference in neither the GA nor the control groups. Regarding the metabolic parameters, fasting plasma glucose was significantly reduced by $26.24 \%$ in the GA group $(145.61 \pm 38.82 \mathrm{vs}$. $197.43 \pm 62.09$ pre-intervention, $\mathrm{p}<0.05)$, HbA1C decreased by $8.8 \%$ in GA group ( $8.42 \pm 1.73$ vs. $9.23 \pm 2.10$ pre-intervention, $\mathrm{p}<0.05$ ) (Table 3 ). A significant change was observed in LDLcholesterol by $19.2 \%$, and there was a borderline reduction in the level of Triglyceride within GA group by $10.95 \%$. However, there was obvious significant increase in the HDL serum level 
$(50.87 \pm 23.48$ vs. $42.43 \pm 15.16$ pre-intervention, $\mathrm{p}<0.05)$. The serum Total-cholesterol was significantly reduced by $8.28 \%$ within GA group (Table 3 ). There were no significant changes in all of these parameters in the placebo group except a significant border line increase of total cholesterol level.

\section{GA tolerance and side effects}

Patients developed minor side effects during the first week of the intervention and follow-up period. Mainly they complained of viscous sensation, diarrhea, nausea, and abdominal bloating. However, these symptoms subsided within the second week of intake, with only the discomfort of viscous sensation continuing through the interventional study, even though patients were on regular consumption of Gum.

Table 4: Side effects of GA among GA group

\begin{tabular}{llll}
\hline Complain & Yes & \multicolumn{1}{c}{ NO } \\
pTotal No. (\%) & Total \\
\hline Abdominal Bloating & $6(13)$ & $40(87)$ & 46 \\
Diarrhea & $11(24)$ & $35(76)$ & 46 \\
Discomfort with viscous sensation & $32(70)$ & $14(30)$ & 46 \\
Nausea & $8(17)$ & $38(83)$ & 46 \\
\hline
\end{tabular}

\section{DISCUSSION:}

This is the first clinical trial to emphasize the nutritional hypoglycemic and hypolipidemic effect of GA on type 2 diabetic patients. In our study, a dose of $30 \mathrm{~g}$ /day significantly reduced FPG and HbA1c $(p<0.05)$, while a previously suggested mechanism in animal studies proposed that the GA decrease expression of intestinal $\mathrm{Na}+$ coupled glucose carrier by down regulating sodium glucose transporter1 (SGLT1) carrier with delay in intestinal glucose transport in diabetic mice treated with GA [16], this delay leading to the slow absorption of macronutrients, which is usually linked to changes in gut peptides resulting in the reduction of postprandial glycemia; on the other hand, the down regulation of SGLT1 leads to the enhancement of hunger related hormones including leptin, cholecystokinin, and glucagon like peptide 1 [17-20]. These hormones decrease hunger by improving post meal satiety through many mechanisms.

Additionally, because this is a mechanistic study based on the response of FPG and HbAlc to $30 \mathrm{~g}$ in diabetic patients, the effect of high dose of GA on postprandial blood glucose, satiety hormones, along with glucose-lowering medication, needs to be investigated.

We discovered that the intake of GA with daily diet decreased BMI, with no significant effects on waist circumference. Our results support previous studies in which GA modifies the body weight and decreased body mass index among healthy adult females [12], reduced weight in rats [21], and reduced visceral adipose tissues in female mice [22].

In our study, the changes in anthropometric measurements might be attributed to the satiety stimulation effect by high fiber intake [23], which is associated with beneficial effects on fat metabolism or lowering caloric density of food [24]. 
Unfortunately, we did not measure the total caloric intake from carbohydrate, fats, and protein for each group. Moreover, GA has an intrinsic glycemic index near to zero and within itself gives less energy if large quantities are taken.

Animal studies on lipid-lowering effect of GA in the past few years have demonstrated conflict results [21, 25-27]. In human results, conflict is mainly related to dose and duration of GA consumption [11, 28-32], as the higher dose and prolonged duration can bring a significant improvement of the lipid profiles. However, the tolerability and compliance of a high dose along with hypoglycemic medication is unclear and need to be investigated further.

In our study, we found that GA treatment significantly decreased the total cholesterol by $8.3 \%$, triglycerides by $10.9 \%$, LDL $19.2 \%$, and significantly increased HDL level by $19.9 \%$ among GA treated group.

The mechanism by which GA intake reduces the plasma cholesterol level may be related to the hypocholesterolemic effect of dietary fibers, which can be explained by many mechanisms, including viscosity effect of dietary fibers [6], increase fecal bile acids, alteration of lipid metabolism [32] and increase number of lipoprotein receptors in the liver [33].

Although this study demonstrated that the consumption of $30 \mathrm{~g}$ of GA improves nutrition of type 2 diabetic patients by improving FPG, HbA1c, and lipid profiles, there are some important limitations. Patients were treated with metformin alone or combination of drugs; these medications have different pharmacological effects. Therefore, further studies based on the types of drugs could be considered in the future.

\section{CONCLUSIONS}

The 3-month trial confirmed that regular ingestion of 30g/day of Gum Arabic (Acacia Senegal) leads to a range of metabolic changes that deserve attention as dietary supplements for improving nutritional value of type 2 diabetic patients with inexpensive and safe type of soluble dietary fiber. Future studies are needed to consider this approach in obese and pre-diabetic subjects.

\section{Competing Interest:}

The authors have no financial interest or conflicts of interest.

\section{Authors' Contributions:}

RB conducted the study, acquisition of measurements and data, followed the study, generated the idea and drafted the manuscript. KE designed and revised the methodology, statically analyzed the data and revised the manuscript. MK has been involved in revising it critically for important intellectual content, drafted and revised the manuscript. AB participated in the sequence alignment, coordination and helped to draft the manuscript. AMS made contributions to conception and design, directed the study, drafted and revised the manuscript.

\section{Acknowledgements:}

The trial has taken place at Academy Charity Teaching Hospital (ACTH) at diabetic outpatient clinic with Dr. Ahmed Dirar is acknowledged. 
The authors thank the patients and the Dar Savanna Ltd (safast). Khartoum, Sudan for providing Gum Arabic. Also thank the Organization for Women in Science for the Developing World (OWSD) fellowship to Rasha Babiker for support the research.

\section{REFERENCES:}

1. Sharma S, Cade J, Jackson M, Mbanya JC, Chungong S, Forrester T, et al. Development of food frequency questionnaires in three population samples of African origin from Cameroon, Jamaica and Caribbean migrants to the UK. European journal of clinical nutrition. 1996. p. 479-86.

2. Mennen LI, Jackson M, Sharma S, Mbanya JC, Cade J, Walker S, et al. Habitual diet in four populations of African origin: a descriptive paper on nutrient intakes in rural and urban Cameroon, Jamaica and Caribbean migrants in Britain. Public Health Nutr. 2001;4(3):76572.

3. Danesh J, Erqou S, Walker M, Thompson SG. The Emerging Risk Factors Collaboration: Analysis of individual data on lipid, inflammatory and other markers in over 1.1 million participants in 104 prospective studies of cardiovascular diseases. European Journal of Epidemiology. 2007. p. 839-69.

4. Nelson KM, Reiber G, Boyko EJ. Diet and exercise among adults with type 2 diabetes: Findings from the third national health and nutrition examination survey (NHANES III). Diabetes Care. 2002;25(10):1722-8.

5. Goodrum LJ, Patel A, Leykam JF, Kieliszewski MJ. Gum arabic glycoprotein contains glycomodules of both extensin and arabinogalactan-glycoproteins. Phytochemistry. 2000;54(1):99-106.

6. Marciani L, Gowland P a, Spiller RC, Manoj P, Moore RJ, Young P, et al. Gastric response to increased meal viscosity assessed by echo-planar magnetic resonance imaging in humans. J Nutr. 2000;130(1):122-7.

7. Phillips GO. Acacia gum ( Gum Arabic ): A nutritional fibre; metabolism and calorific value. Food Addit Contam. 1998;15(3):251-64.

8. Ulven T. Short-chain free fatty acid receptors FFA2/GPR43 and FFA3/GPR41 as new potential therapeutic targets. Front Endocrinol. 2012;3(October):111.

9. Min YW, Park SU, Jang YS, Kim YH, Rhee PL, Ko SH, et al. Effect of composite yogurt enriched with acacia fiber and Bifidobacterium lactis. World J Gastroenterol. 2012;18(33):4563-9.

10. Nasir O. Renal and extrarenal effects of gum arabic (Acacia senegal) - What can be learned from animal experiments? Kidney and Blood Pressure Research. 2013. p. 269-79.

11. Sharma RD. Hypocholestolemic Effect of Gum Acacia in Men. Nutr Res. 1985;5:1321-6.

12. Babiker R., Merghani TH., Elmusharaf K., Badi RM., Lang F., Saeed AM. Effects of gum Arabic ingestion on body mass index and body fat percentage in healthy adult females: Two-arm randomized, placebo controlled, double-blind trial. Nutr $\mathrm{J}$ [Internet]. 2012;11(1):1-7. Available from: http://www.scopus.com/inward/record.url?eid=2-s2.084870858554\&partnerID=40\&md5=415610cbc1b1f4f838819c2e63539dd5

13. Anderson DMW, Eastwood MA. The safety of gum arabic as a food additive and its Energy 
Value as an ingredient: a brief review. J Hum Nutr Diet. 1989;2(3):137-44.

14. Group NDD. Classification and diagnosis of diabetes mellitus and other categories of glucose intolerance. National Diabetes Data Group. Diabetes [Internet]. 1979;28(12):1039-57. Available from: http://www.ncbi.nlm.nih.gov/pubmed/510803

15. Cholesterol N, Program E. Third Report of the National Cholesterol Education Program (NCEP) Expert Panel on Detection, Evaluation, and Treatment of High Blood Cholesterol in Adults (Adult Treatment Panel III) final report. Circulation. 2002;106(25):3143-421.

16. Nasir O, Artunc F, Wang K, Rexhepaj R, Föller M, Ebrahim A, et al. Downregulation of mouse intestinal Na-coupled glucose transporter SGLT1 by Gum arabic (Acacia Senegal). Cell Physiol Biochem. 2010;25(2-3):203-10.

17. Dikeman CL, Fahey GC. Viscosity as Related to Dietary Fiber: A Review. Crit Rev Food Sci Nutr. 2006;46(8):649-63.

18. Howarth NC, Saltzman E, Roberts SB. Dietary fiber and weight regulation. Nutr Rev [Internet]. 2001;59(5):129-39. Available from: http://www.ncbi.nlm.nih.gov/pubmed/11396693

19. Mattes RD, Rothacker D. Beverage viscosity is inversely related to postprandial hunger in humans. Physiol Behav. 2001;74(4-5):551-7.

20. Gorboulev V, Schürmann A, Vallon V, Kipp H, Jaschke A, Klessen D, et al. Na +-Dglucose cotransporter SGLT1 is pivotal for intestinal glucose absorption and glucosedependent incretin secretion. Diabetes. 2012;61(1):187-96.

21. Ushida K, Hatanaka H, Inoue R, Tsukahara T, Phillips GO. Effect of long term ingestion of gum arabic on the adipose tissues of female mice. Food Hydrocoll [Internet]. Elsevier Ltd; 2011;25(5):1344-9. Available from: http://dx.doi.org/10.1016/j.foodhyd.2010.12.010

22. Ahmed AA, Musa HH, Fedail JS, Sifaldin AZ, Musa TH. Gum arabic decreased visceral adipose tissue associated with downregulation of $11 \beta$-hydroxysteroid dehydrogenase type I in liver and muscle of mice. Bioact Carbohydrates Diet Fibre [Internet]. 2015;6(1):31-6. Available from: http://linkinghub.elsevier.com/retrieve/pii/S2212619815300048

23. Ye Z, Arumugam V, Haugabrooks E, Williamson P, Hendrich S. Soluble dietary fiber (Fibersol-2) decreased hunger and increased satiety hormones in humans when ingested with a meal. Nutr Res. 2015;35(5):393-400.

24. Ali BH, Ziada A, Blunden G. Biological effects of gum arabic: A review of some recent research. Food Chem Toxicol [Internet]. Elsevier Ltd; 2009;47(1):1-8. Available from: http://dx.doi.org/10.1016/j.fct.2008.07.001

25. Musa HH, Ahmed AA, Musa TH, Fedail JS. Gum Arabic down-regulate PPAR-g and SCD mRNA expression in mice. Polish Ann Med. 2015;22(1):11-7.

26. Tsai AC, Elias J, Kelley JJ, Lin RS, Robson JR. Influence of certain dietary fibers on serum and tissue cholesterol levels in rats. J Nutr [Internet]. 1976;106(1):118-23. Available from: http://www.scopus.com/inward/record.url?eid=2-s2.0-0016883306\&partnerID=tZOtx3y1

27. Ahmed AA, Musa HH, Fedail JS, Sifaldin AZ, Musa TH. Gum Arabic suppressed dietinduced obesity by alteration the expression of mRNA levels of genes involved in lipid metabolism in mouse liver. Bioact Carbohydrates Diet Fibre. 2016;7(1):15-20.

28. Ross a. HM, Eastwood M a., Anderson JR, Anderson DMW. of Dietary Gum Arabic in. Am J Clin Nutr. 1983;37:368-75. 
29. Jensen CD, Spiller GA, Gates JE, Miller AF, Whittam JH. The effect of acacia gum and a water-soluble dietary fiber mixture on blood lipids in humans. J Am Coll Nutr [Internet]. 1993;12(2):147-54. Available from:

http://www.ncbi.nlm.nih.gov/pubmed/8385164\nhttp://www.ncbi.nlm.nih.gov/pubmed/8 385164 ?dopt $=$ AbstractPlus

30. Haskell WL, Spiller GA, Jensen CD, Ellis BK, Gates JE. Role of Water-Soluble Dietary Fiber in the Management of Elevated Plasma Cholesterol in Healthy Subjects. Am Hournal Cardiol. 1992;69(5):433-9.

31. Glover DA, Ushida K, Phillips AO, Riley SG. Acacia(sen) SUPERGUM(TM) (Gum arabic): An evaluation of potential health benefits in human subjects. Food Hydrocoll [Internet]. 2009;23(8):2410-5.Available from: http://www.sciencedirect.com/science/article/pii/S0268005X09001416

32. Moundras C, Behr SR, Rémésy C, Demigné C. Fecal losses of sterols and bile acids induced by feeding rats guar gum are due to greater pool size and liver bile acid secretion. J Nutr. 1997;127(6):1068-76.

33. Fernandez ML, Ruiz LR, Conde AK, Sun DM, Erickson SK, Mcnamara DJ, Psyllium reduces plasma LDL in Guinea-pigs by alterting hepatic cholesterol homeostasis. J Lipid Res. 1995;36(5):1128-38. 